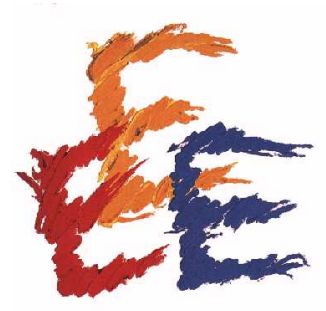

Fondazione Eni Enrico Mattei

\title{
The Impacts of Climate Change on Water Resources of Lebanon- Eastern Mediterranean
}

\author{
Mohamad R. Khawlie*
}

NOTA DI LAVORO 45.2001

JUNE 2001

NRM - Natural Resources Management

*National Centre for Remote Sensing (of NCSR),

Beirut, Lebanon

This paper can be downloaded without charge at:

The Fondazione Eni Enrico Mattei Note di Lavoro Series Index: http://www.feem.it/web/activ/_activ.html

Social Science Research Network Electronic Paper Collection: http://papers.ssrn.com/abstract=278513

Fondazione Eni Enrico Mattei

C.F. 97080600154 
The Impacts of Climate Change on Water Resources of Lebanon- Eastern Mediterranean

Socioeconomic Impacts of Global Change in the Mediterranean: Impacts, Adaptation, and Mitigation Co-Benefits A RICAMARE Workshop FEEM, Milan, Italy, February 9-10, 2001

Mohamad R. Khawlie

National Center for Remote Sensing (of NCSR)

Beirut-Lebanon

E-mail: mkhawlie@cnrs.edu.lb

Keywords: climate change, water, vulnerability, socio-economic, adaptations

Classification- JEL

Q2: Renewable resources and conservation; Environmental Management

Q24: Water 


\section{Introduction}

Obviously, talking about water resources in a region like the Middle East, where they are scarce (Sadek \& Barghouti, 1994; ACSAD, 1998), is a matter of utmost significance. It must be made clear from the beginning that this also applies to Lebanon, inspite of what some authors erroneously point out that Lebanon is rich with water (Allan, 1994).

There are increasing problems facing the water sector in Lebanon making it more difficult to encounter them with the classical management approaches being followed (Khawlie, 1999). Both natural causes and human interferences are adding cumulatively to further the extent of deterioration, quantitatively and qualitatively. There is a definite need to upgrade the water sector, and to secure its sustainability.

The problem is due to several causes:

- Improper management: conventional and non-conventional sources

- Inadequate financial resources

- Lacking accurate and total-integrated information

- Inappropriate life-style (wastage)

- Lacking relevant legislation and implementation

- Lacking relevant awareness (participation)

A new dimension has to be added to the above, namely the impact of climate change (CC). The $\mathrm{CC}$ especially affects the following crucial issues of the water sector in Lebanon: 
- The supplies

- The sources

- The availability: sectors, utilization

- The management

\section{Water Databases and Climate Projection}

The best way to reflect on this is the water balance, Table 1, and the demand-supply picture of the country (Fig. 1) (Khawlie, 1999). Table 1 shows estimates of the supply-demand which is not necessarily the most accurate, but it is the best data available. One basic problem with the supply is that rain distribution varies geographically (different microclimates from arid to humid to oromediterranean) and varies also temporally, being episodic and torrential. Moreover, since in many areas the water distribution network is old or lacking, this implies considerable wastage.

Generally, there is lack of a systematic on-going monitoring operation of the water quality in Lebanon. Considerable work, however, was carried out by help of international institutions, e.g. UNESCO, or through individual researchers (Jurdi, 1995; Dia, 1995; Darwish et al., 2000). Although the results cover wide areas in Lebanon, yet they do not provide a reliable timeframe of updated/upgraded data. The data apply to the time when those investigations were carried out.

As such, it is not an easy task to give an accurate updated picture of water pollution in Lebanon, and Table 2 gives an overview of its status. One can clearly notice by studying Table 2 that all geographic areas are being exposed to different degrees of polluted water, and the picture is 
serious. Indeed, the recurrence of annual diseases due to water problems is very common, especially in the rural and several suburban areas. Databases in Lebanon are not quite consistent and accurate, implying difficulty in interpreting correctly trends of change. Actual records on water supply, e.g. precipitation, reflect a decreasing pattern over the last century. This is in agreement with predicted trends of temperature and precipitation values obtained from the GCM models over Lebanon. The HadCM2/HHGGax model predicts an average of $1.6^{\circ} \mathrm{C}$ increase in temperature by the year 2020, and an equivalent average of about $3 \%$ less precipitation. Indicators of change can be monitored as they are reflected in: reduced water quantities and soil moisture, in desertified areas, in increased water pollution and environmental deterioration.

\section{Socioeconomic Impacts}

A look over the following expected impacts resultant from climate change reflects the inherent interrelationship to water. Under each of the three categories, or concerns, i.e. resources, natural settings and human settings, water deficiencies would affect (or be affected) either directly or indirectly by climate change-induced problems. 


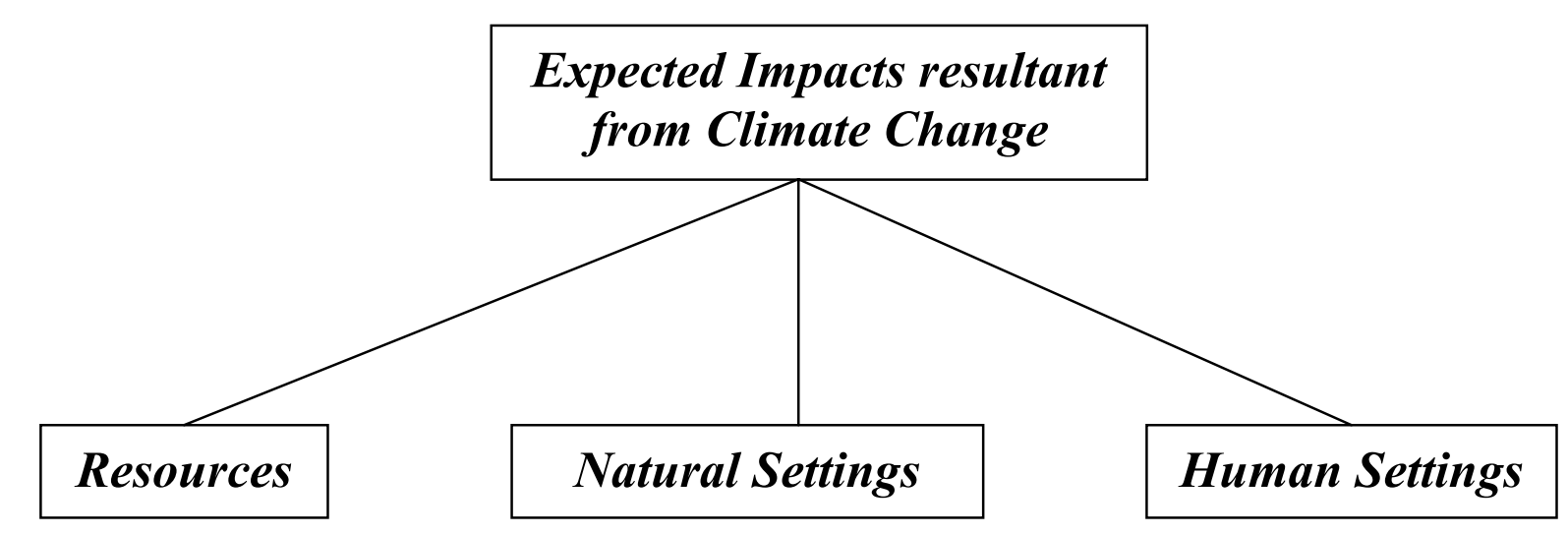

- Water

$$
\begin{aligned}
& + \text { quantity } \\
& + \text { quality }
\end{aligned}
$$

- Forests

- Biodiversity

- Fisheries
- Inland Zone

- Agriculture

+ torrential flooding

+ desertification

+ soil degradation

- Coastal Zone

Exposure Units

+ inundation/flooding

+ loss of land

+ salt-water intrusion

- Living Standards

- Ecosystems

+ marine

+ terrestrial

+ wetlands
- Social Conflicts

- Energy \& Industry

- Settlement \& Land-use

- Productivity

- Protected Areas 
Obviously, with less water one expects problems with forestry, or with wetlands and relevant ecosystems, or with any/all human practices that rely on water ... as indeed is shown above.

In this regard, and in view of the overwhelming problem at hand, one could focus on what likely are to be the most significant impacts, or what is more vulnerable. Three types of study: analogues, field surveys and expert judgment reveal an interesting picture emerging in a cross impact analysis approach (as shown in Fig. 2-A). Thus analogues cover such aspects as living standards, diseases, social conflicts, forestry and agriculture. Similarly, other approaches cover other aspects as applicable. For expert judgment, different specialists were contacted to find out their opinions. In Fig. 2(A) a cross impact structural analysis is shown, with variables reflecting impact of climate change and how they are influenced by the water sector. This is then used to construct the driving power/dependency chart, Fig. 2(B), which allows to categorize the variables into four types: "autonomous" (weak drivers and weakly dependent on climate change), "relay" (strong drivers and strongly dependent), "result" variables which obviously are strongly dependent and weak drivers, and "forcing", i.e. strong drivers but weakly dependent. Obviously, the most vulnerable are the "relay" variables, particularly water quantity, water quality, productivity and living standards.

\section{Adaptation Measures and Recommendations}

Adaptability and adaptation are: "Adaptability refers to the degree to which adjustments are possible in practices, processes or structures of 
systems to projected or actual changes of climate. Adaptation can be spontaneous or planned, and can be carried out in response to or in anticipation of changes in conditions" (IPCC, 1996). In this respect it is necessary to find out where or how climate change effects on a system are most pronounced. Thus, in reference to the effects on water resources, and in view of the fact that water impacts the whole social structure, it is necessary to consider adaptation at three levels: the strategic, the population, and the individual level (Klein \& Tol, 1997).

Figure 3 reflects on major adaptation opportunities of water resources facing climate change conditions as revealed in this paper. The strategic level considers development and implementation policies and programs to help people adapt to climate change. At the population level, the concern is geared towards protection or prevention of impacts. This leaves adaptation at the individual level which focuses on behavioral adjustments. The other data in the Figure identify the opportunities and classify them under different generic approaches for coping with the effects of climate change. As obvious, those approaches could lead to adaptation through various means i.e. preventive measures, sharing losses, changing attitudes and restoring or applying some technologies on quality control.

The three priorities of the adaptation opportunities can also be linked to a framework of time. This serves a more pragmatic 3-phase recommendation framework as follows:

Phase 1- immediate implementation (within the year 2001)

- policies to enhance better monitoring of sectoral water use, adoption of quality standards and enforcing environmental laws 
- short-term strategy for watershed management and upgrading of water network and services including gauging stations nationwide

- assure functional operation and sectoral needs prioritization

- assure availability of preventive means to face water-borne diseases

- spreading of knowledge and capacities for appropriate practices during disasters

- implement local community-based monitoring systems for water quality

- restoration of secondary enrichment of depleted aquifers

- reenhancement of water reservoirs of the "Green Plan"

Phase 2- medium term implementation (within the year 2005)

- long-term strategy on equity management of water resources

- policies and incentives to enhance changing patterns of water use

- enforce policies to control water resource quality especially from sewage, wastewater, and agrochemicals

- policies and programs to implement a series of small earth dams to increase amounts of available surface water notably on rivers of international waters

- long-term strategy to rehabilitate forests and degraded land to upgrade forestry and soil conditions

- upgrade institutional capabilities and capacity building in climatic stations and databases

- devise mechanisms to reduce water stress on geographic basis 
- apply more efficient ways and means to face increased shortages at community level

- regulate all sectoral uses of water at all levels

- devise new technologies reusing smaller amounts of water

- introduce concepts and demos at educational institutions on "friendly" use and conservation of water

- reorganization of water management to become more effective and modern

- public awareness on water wastage, conservation practices, and quality control

- selective application of water conservation technologies

- capacity building for individuals to share resources, to cooperate during stress, and accept more stringent conditions in water use

- public awareness campaign on benefits of changing water use patterns

- capacity building and awareness on benefits of quality control practices

Phase 3- long-term implementation (within the year 2010)

- policies to develop innovative means of using unconventional sources of water

- policies to strengthen market mechanisms and financial incentives in water use and pricing

- policies to enhance cost sharing of water demand by private sector 
- long-term strategy to reduce densely populated areas with water problems

- long-term strategy to reduce water-demanding activities in dry areas

- regulate pumping of subsurface water to prevent stressing the water table

- tolerable sectoral water use standards

- R \& D on efficient approaches to relocate high water demand activities

- accept less luxurious ways of living

\section{References}

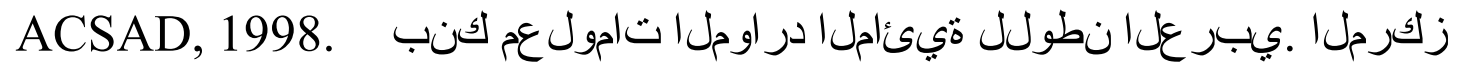

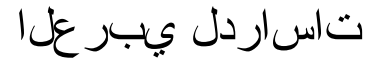

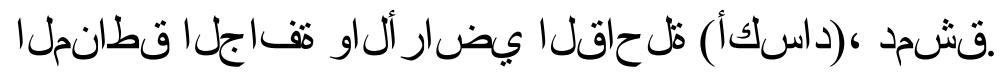

Allan, J.A., 1994. Overall perspectives on countries and regions. in: Water in the Arab World: Perspectives and Prognoses. Rogers \& Lydon (ed.), AUC Press, Egypt.

Darwish, T.; Jomaa, I.; \& Sukkarieh, W., 2000. Modeling of the transfer of heavy metals from soil to groundwater. Presented in the Workshop on Soil and Groundwater Vulnerability to Contamination. ACSAD/BGR/NCSR, Beirut. 
Dia, A., 1995. Impact des pollutions organiques sur un cours d'eau de Jabboule (Bassin supérieur du Nahr el-A'ssi- Oronte). Presented to the $1^{\text {st }}$ National Conference on Environmental Management for Sustainable Development in Lebanon. NCSR, Beirut.

IPCC, 1996. Summary for policymakers: scientific-technical analysis of impacts, adaptations, and mitigation of climate change. in: Climate Change 1995- the Second Assessment Report of IPCC. Cambridge University Press. 1-18.

Jurdi, M., 1995. Potable water in Lebanon: Quality and quantity control program. Presented to the $1^{\text {st }}$ National Conference on Environmental Management for Sustainable Development in Lebanon. NCSR, Beirut.

Khawlie, M., 1999. Water Resources: Assessment of Lebanon's Vulnerability to Climate Change. Lebanon's National Communication on Climate Change. Ministry of Environment, UNDP, GEF. Beirut.

Klein, R., \& Tol, R., 1997. Adaptation to climate change: Options and technologies- An overview paper. Intl. Env. Studies E97/18.

Sadek, A.K., \& Barghouti, S., 1994. The water problems of the Arab World: Management of scarce resources. in: Water in the Arab World: Perspectives and Prognoses. Rogers \& Lydon (ed.), AUC Press, Egypt. 


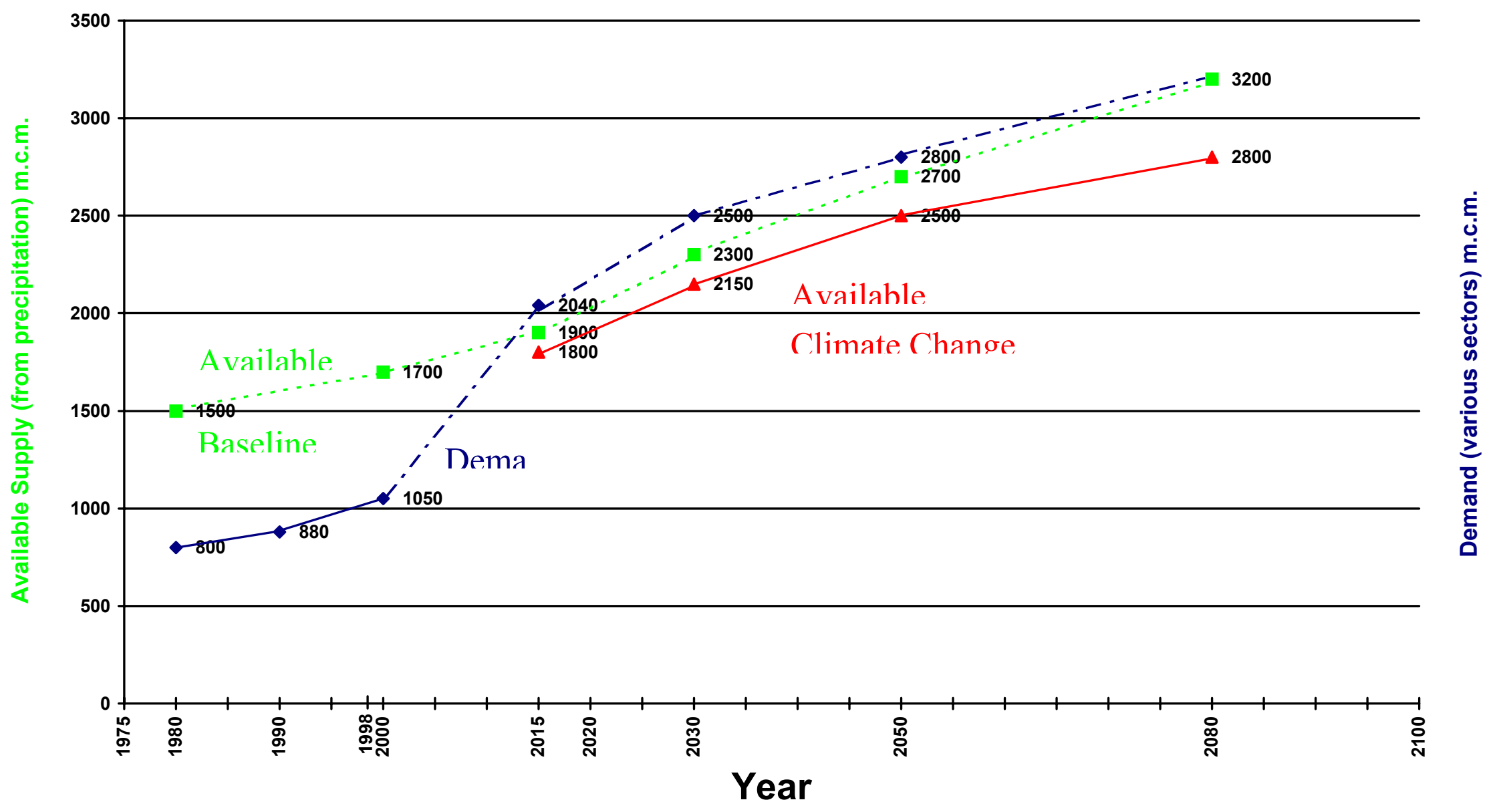

Figure 1. Climate Change Projection, Water Supply-Demand 


\begin{tabular}{|c|c|c|c|c|c|c|c|c|c|c|c|c|c|c|c|c|}
\hline & & 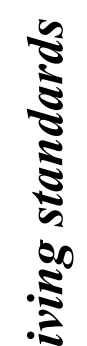 & 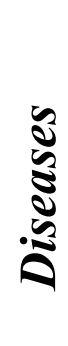 & 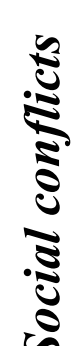 & 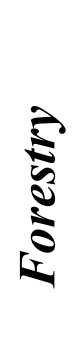 & 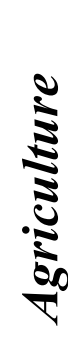 & 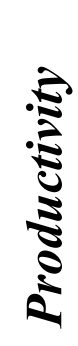 & 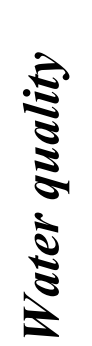 & 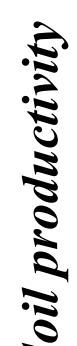 & $\underset{\mathbb{Z}}{\mathbb{\Xi}}$ & 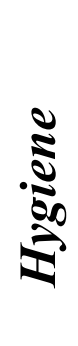 & 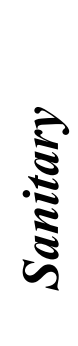 & 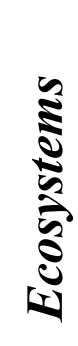 & 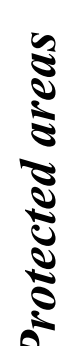 & 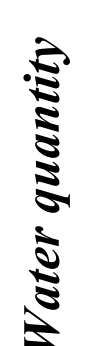 & 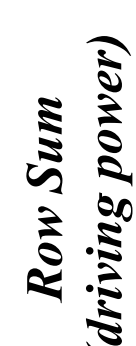 \\
\hline \multirow{6}{*}{ 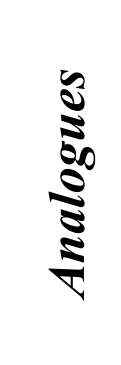 } & Impact & & & & & & & & & & & & & & & \\
\hline & Living standards & & 1 & 1 & & & 1 & 1 & & & 1 & 1 & & 1 & 1 & 8 \\
\hline & Diseases & 1 & & 1 & & & & 1 & & & 1 & 1 & & & 1 & 6 \\
\hline & Social conflicts & 1 & 1 & & & & & 1 & & & 1 & 1 & & & 1 & 6 \\
\hline & Forestry & 1 & & 1 & & 1 & 1 & 1 & 1 & 1 & & & 1 & 1 & 1 & 10 \\
\hline & Agriculture & 1 & & 1 & 1 & & 1 & 1 & 1 & 1 & & & 1 & 1 & 1 & 10 \\
\hline \multirow{4}{*}{ 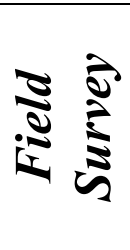 } & Productivity & 1 & & 1 & 1 & 1 & & 1 & 1 & 1 & 1 & 1 & & & 1 & 10 \\
\hline & Water quality & 1 & 1 & 1 & 1 & 1 & 1 & & 1 & 1 & 1 & 1 & 1 & 1 & 1 & 13 \\
\hline & Soil productivity & 1 & & 1 & 1 & 1 & 1 & 1 & & & & & 1 & 1 & 1 & 9 \\
\hline & Wetlands & 1 & 1 & 1 & 1 & 1 & 1 & 1 & & & & & 1 & 1 & 1 & 10 \\
\hline \multirow{5}{*}{ 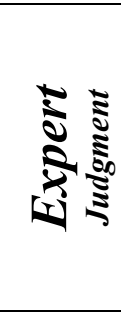 } & I. Hygiene & 1 & 1 & 1 & & & 1 & 1 & & & & 1 & & & 1 & 7 \\
\hline & Sanitary & 1 & 1 & 1 & & & 1 & 1 & & & & 1 & & & 1 & 9 \\
\hline & Ecosystems & & & & 1 & 1 & 1 & 1 & 1 & 1 & & & & 1 & 1 & 8 \\
\hline & Protected areas & 1 & & & 1 & 1 & 1 & 1 & 1 & 1 & & & 1 & & 1 & 9 \\
\hline & Water quantity & 1 & 1 & 1 & 1 & 1 & 1 & 1 & 1 & 1 & 1 & 1 & 1 & 1 & & 13 \\
\hline \multicolumn{2}{|c|}{ Column Sum (dependency) } & 12 & 7 & 11 & 8 & 8 & 11 & 13 & 7 & 7 & 6 & 8 & 7 & 8 & 13 & \\
\hline
\end{tabular}

Figure 2(A). Cross Impact Analysis 

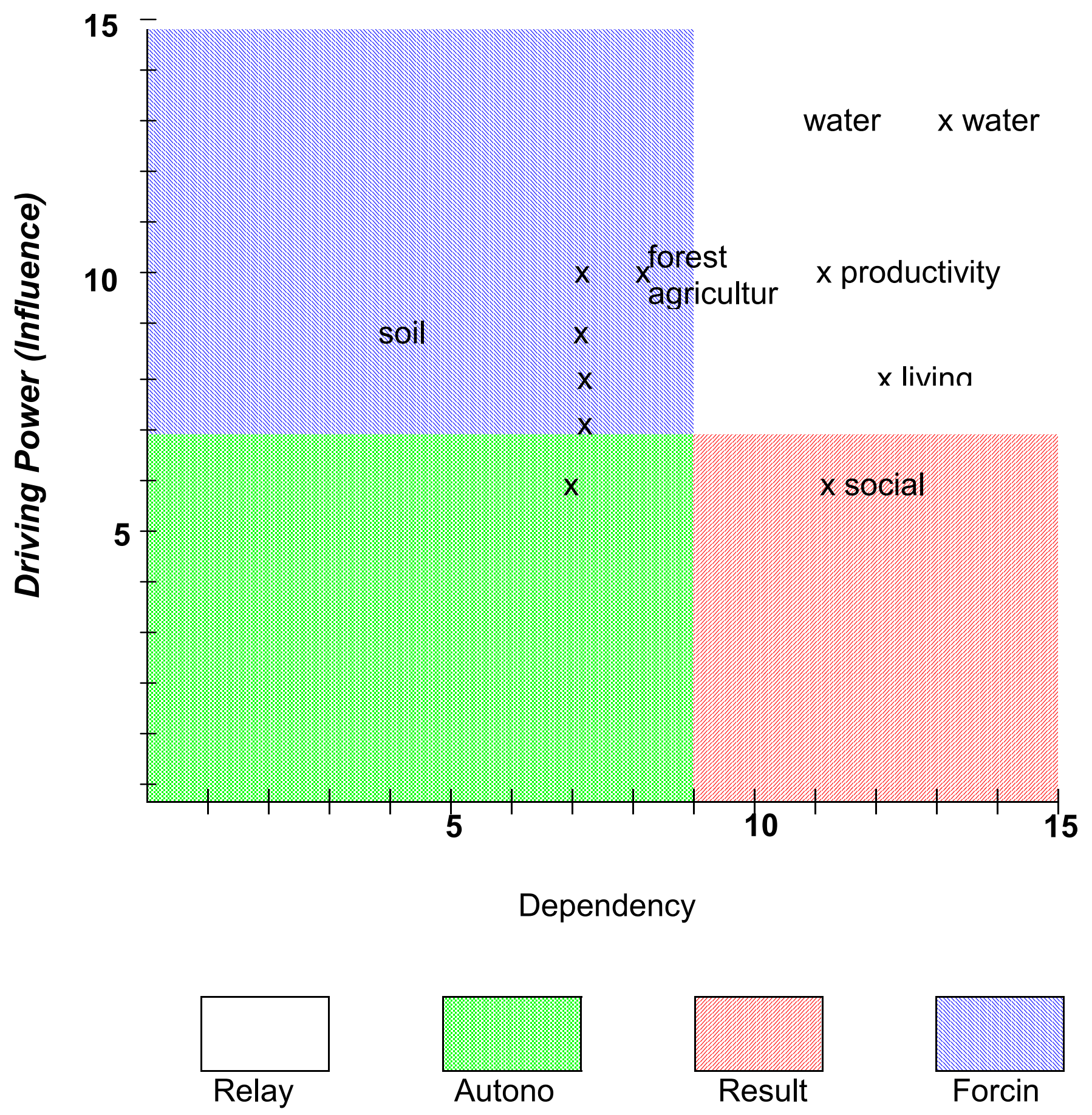

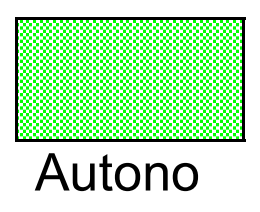

mous

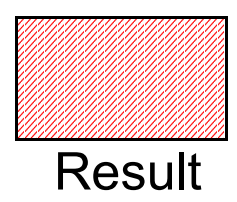

Result

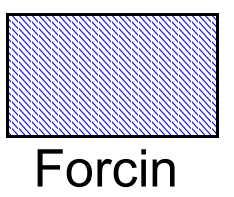

g

Figure 2(B). Categories of variables impacted by climate change 


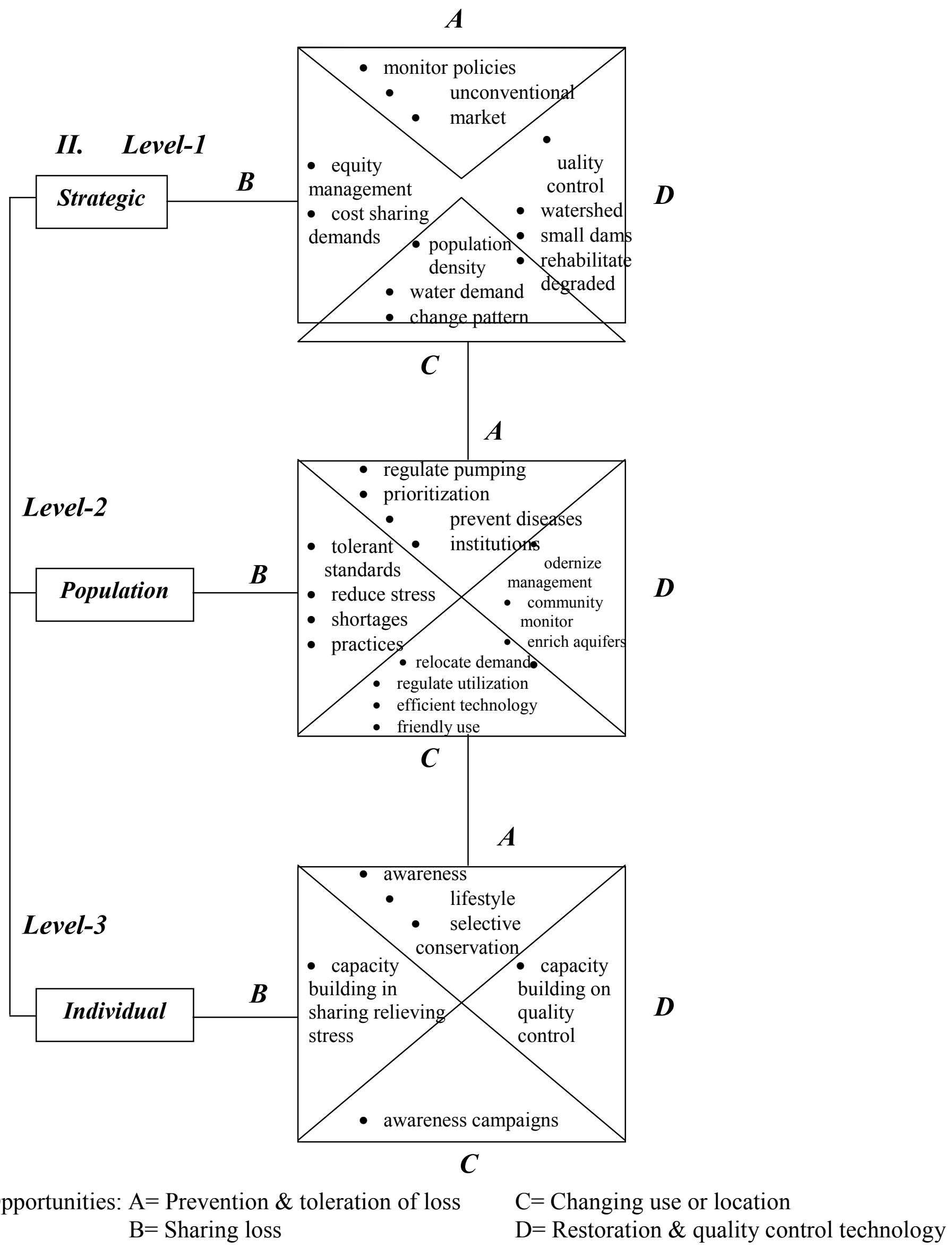

Figure 3. Major adaptation opportunities for water resources facing Climate Change 
Table 1. Ranges of estimated data on sectoral use of water resources, and supply-demand, (Khawlie, 1997-different sources)*

\begin{tabular}{|c|c|c|c|c|c|c|}
\hline \multicolumn{3}{|c|}{$\begin{array}{l}\text { Total Precipitation (Supply) } \\
\text { (+ snow) } \\
\text { b.c.m. } \\
8.6-9.7\end{array}$} & \multicolumn{4}{|c|}{$\begin{array}{l}\text { Total Demand } \\
\text { (major uses) } \\
\text { m.c.m. } \\
900-1460\end{array}$} \\
\hline \multirow[t]{2}{*}{$\begin{array}{l}\text { surface } \\
\text { water } \\
1.4-4.2\end{array}$} & \multirow[t]{2}{*}{$\begin{array}{l}\text { subsurface } \\
\text { water } \\
0.6-3.8\end{array}$} & \multirow[t]{2}{*}{$\begin{array}{l}\text { lost out } \\
2.3-3.0\end{array}$} & \multirow[t]{2}{*}{$\begin{array}{c}\text { agriculture } \\
\text { (irrigation) } \\
670-890\end{array}$} & \multicolumn{2}{|c|}{$\begin{array}{l}\text { residential } \\
(80-420) \\
\text { per capita } \\
1 / \mathrm{d}\end{array}$} & \multirow[t]{2}{*}{$\begin{array}{c}\text { industrial } \\
50-150\end{array}$} \\
\hline & & & & $\begin{array}{l}\text { urban } \\
250- \\
300\end{array}$ & $\begin{array}{l}\text { rural } \\
150- \\
200\end{array}$ & \\
\hline \multicolumn{3}{|c|}{$\begin{array}{c}\text { projected average annual } \\
\text { decrease in precipitation }= \\
1.11 \% * *(\max 0.9 \%)\end{array}$} & \multicolumn{4}{|c|}{$\begin{array}{l}\text { projected annual increase in water } \\
\text { needs }=3.52 \% * *(2.0 \%)\end{array}$} \\
\hline \multicolumn{7}{|c|}{$\begin{array}{l}\text { An integrated estimate (b.c.m.): } \\
\text { (Maksoud, personal communication) } \\
3.30\end{array}$} \\
\hline \multicolumn{7}{|c|}{$\begin{array}{l}\text { Estimated projections of available water: }-1995=1.46 \text { b.c.m. } \rightarrow 2015= \\
2.70 \text { b.c.m. } \\
\begin{array}{ll}(U N D P, 1997) & \text { - Deficit in } 2015=800 \text { m.c.m. }\end{array}\end{array}$} \\
\hline
\end{tabular}

* As can be obviously seen in the Table, there is a wide range in the estimated values of supply, demand and projections. This, unfortunately, makes arriving at an accurate baseline questionable.

** These two projections sound rather high. The regression lines of Beirut 100 years precipitation (Figure 1-1) do not indicate a decrease exceeding maximum $0.9 \%$. As for increase in water needs, several workers put it more realistically at about $2.0 \%$ maximum. This is because of water conservation and other environment-friendly practices that would be expectedly employed in the near future. 
Table 2. Overview of the status of water pollution in Lebanon reflecting on its quality*

\begin{tabular}{|c|c|c|c|c|}
\hline \multirow[b]{2}{*}{ 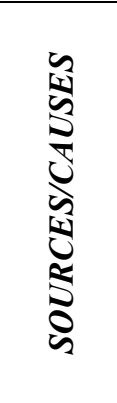 } & \multicolumn{2}{|l|}{ Direct } & \multicolumn{2}{|c|}{ Indirect** } \\
\hline & \multicolumn{2}{|c|}{$\begin{array}{l}\text { status of waste water/sewage network } \\
\text { industrial enterprises (food, materials, energy) } \\
\text { solid waste open dumps } \\
\text { farms \& animal husbandries } \\
\text { quarries \& construction debris } \\
\text { hospitals } \\
\text { fuel stations \& car repair shops } \\
\text { fertilizers \& (herbi + insecti)-cides } \\
\text { salt-water intrusion }\end{array}$} & \multicolumn{2}{|c|}{$\begin{array}{ll}\text { - } & \text { lack of agro-directives } \\
\text { - } & \text { lack monitor/control } \\
\text { - } & \text { air pollution } \\
\text { - } & \text { den-separation of different services networks } \\
\text { - } & \text { increase uncontral rejuvenation } \\
\text { - } & \text { improper management pumping/exploitation } \\
& \text { lack of data }\end{array}$} \\
\hline \multirow[b]{2}{*}{ 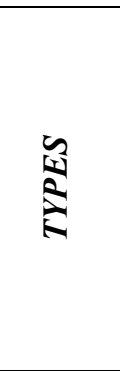 } & \multicolumn{2}{|l|}{$A=$ Chemical } & $B=$ Biological & $C=$ Physical \\
\hline & $\begin{array}{l}\text { A-1. heavy metals } \\
\text { A-2. toxics } \\
\text { A-3. (h) above } \\
\text { A-4. salts } \\
\text { A-5. radioactive } \\
\text { A-6. COD } \\
\text { A-7. excessive other elements }\end{array}$ & $\begin{array}{l}\text { (organic) } \\
\text { A-8. hydrocarbons } \\
\text { A-9. (h) above } \\
\text { A-10. (f) above } \\
\text { A-11. BOD } \\
\text { A-12. organic waste }\end{array}$ & $\begin{array}{l}\text { - biological } \\
\text { - bacteria } \\
\text { - virus } \\
\text { - algae } \\
\text { - others }\end{array}$ & $\begin{array}{l}\text { - sediments } \\
\text { - suspended water } \\
\text { - heat } \\
\text { - color } \\
\text { - taste } \\
\text { - smell }\end{array}$ \\
\hline \multirow{9}{*}{ 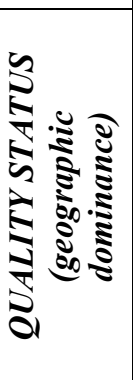 } & \multirow{2}{*}{ Area } & \multicolumn{3}{|l|}{ Extent of Pollution } \\
\hline & & High & Moderate & Low \\
\hline & Dense urbanized areas & $\mathrm{a}, \mathrm{b}, \mathrm{c}, \mathrm{f}, \mathrm{g}, \mathrm{i}$ (coastal) $\mathrm{B}$ & $\mathrm{A}-4, \mathrm{~A}-8, \mathrm{~A}-10, \mathrm{~A}-12, \mathrm{C}$ & A-1, A-2, (A-5?) \\
\hline & Akkar & a, c, d, h, i, B & $A-12, C$ & $\mathrm{~b}, \mathrm{e}, \mathrm{f}, \mathrm{g}, \mathrm{A}-1, \mathrm{~A}-2$ \\
\hline & Other coastal plains & $\mathrm{a}, \mathrm{c}, \mathrm{i}$ & $\mathrm{b}, \mathrm{f}, \mathrm{g}, \mathrm{h}, \mathrm{A}-12, \mathrm{~B}, \mathrm{C}$ & A-1, A-2, (A-5?) \\
\hline & \multirow{2}{*}{ Coasta slopes up to $1200 \mathrm{~m})$} & $\mathrm{a}, \mathrm{c}, \mathrm{e}, \mathrm{A}-12$ & $\mathrm{~b}, \mathrm{~d}, \mathrm{f}, \mathrm{g}, \mathrm{h}, \mathrm{B}$ & $\mathrm{A}-1, \mathrm{~A}-2,(\mathrm{~A}-5 ?), \mathrm{C}$ \\
\hline & & $\mathrm{a}, \mathrm{c}, \mathrm{d}$ & $\mathrm{e}, \mathrm{h}, \mathrm{B}$ & $\mathrm{b}, \mathrm{f}, \mathrm{g}, \mathrm{A}-\mathrm{A}, \mathrm{A}-12, \mathrm{C}$ \\
\hline & \multirow{2}{*}{$\begin{array}{l}\text { Beka'a plain } \\
\text { Anti-Lebanon slopes }\end{array}$} & $\mathrm{a}, \mathrm{c}, \mathrm{d}, \mathrm{h}, \mathrm{A}-12$ & $\mathrm{~b}, \mathrm{e}, \mathrm{g}, \mathrm{i}, \mathrm{B}, \mathrm{C}$ & $f, A-2, A-4$ \\
\hline & & $\mathrm{a}, \mathrm{c}, \mathrm{e}$ & $\mathrm{d}, \mathrm{h}$ & $\mathrm{b}, \mathrm{f}, \mathrm{g}, \mathrm{A}-12, \mathrm{~B}, \mathrm{C}$ \\
\hline
\end{tabular}

* Wherever surface water or land surface is polluted, it is highly likely that this affects groundwater as well. This explains the high incidence of organic pollution (ranging from 70\%-80\%) of drinking water- see Table 5.

** Essentially, these aspects affect the quality of water all over Lebanon. 